\title{
Pengaruh Kompetensi dan Insentif Terhadap Kinerja Karyawan Pada PT. Hijau Lestari Raya Fibreboard Pematang Palas
}

\author{
Adi Esti Mulyasari ${ }^{1}$, Rismansyah ${ }^{2}$, Benny Usman ${ }^{3}$ \\ ${ }^{1}$ Manajemen, F. Ekonomi dan Bisnis, Univ. PGRI Palembang, hestimulyasari9@gmail.com \\ ${ }^{2}$ Manajemen, F. Ekonomi dan Bisnis, Univ. PGRI Palembang rismansyah@univpgri-palembang.ac.id \\ ${ }^{3}$ Manajemen, F.Ekonomi dan Bisnis, Univ.PGRI Palembang, benny usman@univpgri-palembang.ac.id
}

\begin{abstract}
ABSTRAK
Penelitian ini bertujuan untuk mengetahui Pengaruh Kompetensi dan Insentif Terhadap Kinerja Karyawan pada PT. Hijau Lestari Raya Fibreboard Pematang Palas. Populasi dalam penelitian ini adalah 210 karyawan yang merupakan seluruh jumlah karyawan di PT. Hijau Lestari Raya Fibreboard Pematang Palas. Sampel pada penelitian ini menggunakan metode dengan rumus slovin dengan karyawan berjumlah 68 orang. Metode pengumpulan data dilakukan dengan menggunakan kuisioner. Teknik analisis data yang digunakan adalah analisis regresi linear berganda, koefisien korelasi, koefisien determinasi, uji t dan uji $\mathrm{F}$ dengan menggunakan program spss for windows versi 22. Hasil pengujian hipotesis uji $t$ secara parsial antara variabel Kompetensi Terhadap Variabel Kinerja Karyawan diperoleh nilai sig 0,004 < signifikan 0,05. Maka disimpulkan ada pengaruh yang signifikan antara Kompetensi Terhadap Kinerja Karyawan. Hasil uji t untuk variabel Insentif Terhadap variabel Kinerja Karyawan diperoleh nilai sig 0,005 < signifikan 0,05. Maka disimpulkan ada pengaruh yang signifikan antara Insentif Terhadap Kinerja Karyawan pada PT. Hijau Lestari Raya Fibreboard Pematang Palas. Sedangkan hasil penelitian uji F untuk variabel Kompetensi dan Insentif Terhadap Kinerja Karyawan diperoleh nilai sig 0,000 $<0,05$ maka menunjukkan ada pengaruh yang signifikan antara Kompetensi dan Insentif secara bersama-sama terhadap Kinerja Karyawan pada PT. Hijau Lestari Raya Fibreboard Pematang Palas.
\end{abstract}

Kata Kunci : Kompetensi, Insentif dan Kinerja Karyawan

\begin{abstract}
This study aims to determine the Effect of Competencies and Incentives on Employee Performance at PT. Hijau Lestari Raya Pematang Palas Fibreboard. The population in this study were 210 employees which constituted the entire number of employees at PT. Hijau Lestari Raya Pematang Palas Fibreboard. The sample in this study used the method with the Slovin formula with 68 employees. The method of data collection is done by using a questionnaire. The data analysis technique used is multiple linear regression analysis, correlation coefficient, coefficient of determination, $t$ test and $F$ test using the SPSS for windows version 22 program. The results of partial $t$ test hypothesis testing between the variable Competence Against Employee Performance Variables obtained a sig value of 0.004 < significant 0.05. So it is concluded that there is a significant influence between Competence on Employee Performance. The results of the $t$ test for the Incentive variable on the Employee Performance variable obtained a sig value of 0.005 <significant 0.05 . So it is concluded that there is a significant influence between Incentives on Employee Performance at PT. Hijau Lestari Raya Pematang Palas Fibreboard. While the results of the $F$ test research for the variable Competence and Incentives on Employee Performance obtained a sig value of $0.000<0.05$, it shows that there is a significant influence between competence and incentives together on employee performance at PT. Hijau Lestari Raya Pematang Palas Fibreboard.
\end{abstract}

Keywords: Competence, Incentives and Employee Performance

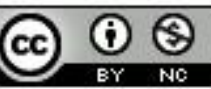




\section{A. PENDAHULUAN}

PT. Hijau Lestari Raya Fibreboard Pematang Palas merupakan suatu perusahaan yang memproduksi kayu karet yang diolah menjadi MDF (Medium Density Fibreboard). Proses pengolahan kayu karet ini terdiri atas beberapa proses antara lain proses pengupasan kayu karet, pemecahan kayu menjadi bentuk korek api dan bentuk kubus, proses peleburan kayu tersebut sehingga berbentuk seperti bubur, pengeleman semprot, pencetakan dengan berbagai macam ukuran ketebalan seperti $6 \mathrm{~mm}-18 \mathrm{~mm}$, kemudian didiamkan selama 3 hari dan diamplas. PT. Hijau Lestari Raya Pematang Palas ini memiliki suatu visi yaitu menjadi produsen panel berbasis kayu terintegrasi kelas dunia yang memadukan pemikiran inovatif. Untuk memimpin industry berbasis kayu yang direkayasa dengan produk dan rencana pertumbuhan yang agresif. Untuk melanjutkan upaya mencapai cakrawala baru dan pencarian tanpa akhir untuk menjadi yang terbaik. Sedangkan misinya yaitu : 1) Untuk menghasilkan MDF, papan partikel, dan produk hilir yang ramah lingkungan, melalui program penghijauan yang dikelola dengan baik dan tenaga kerja yang berkomitmen 2) Untuk mencapai pertumbuhan jangka panjang sambil mempertahankan reputasi kami sebagai produsen terkemuka yang memberikan kepuasan dan kepercayaan kepada pelanggan kami yang berharga 3) Untuk unggul dalam semua operasi dengan meningkatkan proses produksi dan mengurangi biaya. Dilihat dari visi dan misi PT. Hijau Lestari Raya Fibreboard Pematang Palas, maka setiap perusahaan mempunyai tujuan yang ingin dicapai. Dalam mencapai tujuannya setiap perusahaan akan dipengaruhi terhadap perilaku dan sikap individu yang terdapat di perusahaan tersebut. Keberhasilan untuk mencapai tujuan perusahaan tergantung pada kualitas dan kuantitas yang dimiliki karyawan dalam menjalankan tugas dan tanggung jawabnya masing-masing. Tujuan Perusahaan ini merupakan merupakan peran penting dalam mewujudkan visi dan misi yang telah ditetapkan perusahaan, tetapi dalam hal itu untuk mencapai tujuan tersebut perusahaan harus memiliki karyawan yang berkompeten dan mempunyai kinerja yang tinggi. Untuk mencapai hasil yang diinginkan perusahaan harus mempunyai karyawan yang kinerjanya tinggi dan baik sehinga dapat meningkatkan produktivitas kerja dengan itu perusahaan dapat memberikan insentif pada karyawan yang berprestasi (Oktariansyah, 2018). Menurut Sedarmayanti (2017:211) Kompetensi adalah kemampuan yang diharapkan dan menghasilkan yang terbaik. Tidak semua pegawai memiliki kompetensi hanya sebagian yang memiliki kinerja yang baik dan tinggi yang mempunyai kompetensi.

Menurut Kadarisman (2012:198) insentif adalah penghargaan atau ganjaran yang diberikan untuk memotivasi para pekerja agar produktivitas kerjanya tinggi, sifatnya tetap atau sewaktu-waktu.

Menurut Wibowo (2014:7) kinerja adalah tentang melakukan pekerjaan hasil yang dicapai dari pekerjaan tersebut. Namun, sebenarnya kinerja mempunyai makna yang lebih luas, bukan hanya hasil kerja, tetapi bagaimana proses pekerjaan berlangsung.

Kinerja dijadikan sebagai tolak ukur dalam pencapaian seseorang terhadap pekerjaan yang 
dilakukannya, jika kinerja seseorang itu baik maka akan terlihat dari setiap tugas yang diberikan kepadanya, semakin tinggi semangat kerja karyawan akan memberikan hasil yang nyata dengan apa yang dikerjakan dengan tercapainya tujuan perusahaan.

Berdasarkan

observasi

sementara di PT. Hijau Lestari Raya Fibreboard Pematang Palas terdapat masalah kurangnya kemampuan karyawan dalam melaksanakan pekerjaannya. Oleh karena itu fenomena permasalahan yang dihadapi di PT. Hijau Lestari Raya Fibreboard ini adalah kurangnya keterampilan (skill), dan pengetahuan yang seharusnya dimiliki oleh setiap karyawan yang berkompeten dan biasanya didukung oleh sikap kerja yang dituntut perusahaan agar dapat menghasilkan kinerja karyawan yang berprestasi. Selain itu permasalahan yang dihadapi PT. Hijau Lestari Raya Fibreboard ini adanya kecemburuan sosial akan pemberian insentif karena pemberian insentif hanya diberikan kepada karyawan yang memiliki kinerja yang baik, yang mendorong tercapainya prestasi kerja yang tinggi, akan tetapi karena pemberian insentif yang tidak diberikan keseluruh karyawan, membuat karyawan menurun semangat kerjanya sehingga berdampak pada produktivitas perusahaan karena tidak bisa memenuhi permintaan konsumen dan perusahaan akan mengalami kerugian serta hambatan dalam perkembangan perusahaan. Dan bagi karyawan yang memiliki kinerja yang tinggi akan menghambat perkembangan karirnya.

$$
\text { Kompetensi setiap orang }
$$

berbeda-beda karena setiap orang memiliki kemampuan atau keterampilannya sendiri, untuk menggali kompetensi itu perusahaan memberikan insentif bagi karyawan yang memiliki kinerja yang baik dalam melaksanakan tugas yang dibebankan kepadanya.

Menurut Santoso (2016:67) dari hasil penelitian menunjukkan bahwa kompetensi dan insentif berpengaruh secara signifikan terhadap kinerja karyawan. Kompetensi secara parsial berpengaruh terhadap kinerja karyawan. Dan Insentif juga secara parsial berpengaruh terhadap kinerja karyawan pada PG. Madukismo Yogyakarta.

Menurut Lestari (2013:57) dari hasil penelitian menunjukkan bahwa insentif secara stimultan tidak berpengaruh terhadap kinerja karyawan. Insentif secara parsial tidak berpengaruh terhadap kinerja karyawan PT. PLN (Persero) Penyaluran dan Pusat Pengaturan Beban (P3B) Sumatera UPT Palembang.

Menurut hasil penelitian yang dilakukan Basori, Prahiawan, dan Daenulhay (2017:154) menunjukkan bahwa kompetensi dan lingkungan kerja secara bersama-sama tidak berpengaruh terhadap kinerja karyawan. Kompetensi Secara parsial tidak berpengaruh terhadap kinerja. Dan lingkungan kerja secara parsial tidak berpengaruh terhadap kinerja karyawan PT. Krakatau Bandar Samudera.

Berdasarkan hasil penelitian terdahulu diatas diperoleh adanya perbedaan hasil penelitian yang dilakukan oleh para peneliti dan terdapat hasil yang variasi, sehingga mendorong peneliti untuk melakukan penelitian lanjutan yang berhubungan dengan kompetensi dan insentif terhadap kinerja karyawan dengan objek dan data penelitian yang berbeda.

\section{B. KAJIAN TEORI \\ 1) Kompetensi}


a. Pengertian Kompetensi

Menurut Spencer dalam Wibowo (2017:96) bahwa kompetensi adalah segala bentuk sikap, motif, keterampilan, pengetahuan perilaku atau karakteristik pribadi lain yang penting untuk melaksanakan pekerjaan sehingga dapat membedakan antara kinerja rata-rata dengan kinerja superior.

b. Faktor-Faktor Mempengaruhi Kompetensi

yang

Menurut Zwell dalam Wibowo (2017:283) menyatakan bahwa ada 6 faktor yang mempengaruhi kecakapan kompetensi seorang pegawai yaitu:

$\checkmark \quad$ Keyakinan dan nilai, keyakinan orang tentang dirinya maupun terhadap orang lain akan sangat mempengaruhi perilaku.

$\checkmark \quad$ Keterampilan merupakan suatu hal yang dapat dipelajari, dipraktekkan dan diperbaiki.

Pengalaman, keahlian dari banyak kompetensi memerlukan pengalaman mengorganisasi orang, komunikasi dihadapan kelompok, menyelesaikan masalah dan pengalaman merupakan aspek lain kompetensi yang dapat berubah dengan perjalanan waktu dan perubahan lingkungan.

$\checkmark \quad$ Karakteristik kepribadian, dapat mempengaruhi keahlian manajer dan pekerja dan sejumlah kompetensi, termasuk dalam penyelesaian konflik menunjukkan kepedulian interpersonal, kemampuan bekerja dalam tim, memberikan pengaruh dan membangun hubungan. Walaupun dapat berubah, kepribadian tidak cenderung berubah dengan mudah.

$\checkmark \quad$ Motivasi, merupakan faktor dalam kompetensi yang dapat berubah, dengan memberikan dorongan, apresiasi terhadap pekerjaan bawahan.

$\checkmark$ Budaya organisasi, kebiasaan dan prosedur memberi informasi kepada pekerja tentang berapa banyak kompetensi yang diharapkan.

\section{c. Indikator Kompetensi}

Menurut Wibowo (2014:283) ada 7 indikator kompetensi adalah sebagai berikut:

1. Keyakinan dan nilai-nilai

Keyakinan orang tentang dirinya maupun terhadap orang lain akan sangat mempengaruhi perilaku. Apabila orang percaya bahwa mereka tidak kreatif dan inovatif, mereka tidak akan berusaha berpikir tentang cara baru atau berbeda dalam melakukan sesuatu. Untuk itu, setiap orang harus berpikir positif baik tentang dirinya maupun terhadap orang lain dan menunjukkan ciri orang yang berpikir kedepan.

2. Keterampilan

Keterampilan memainkan peran dikebanyakan kompetensi.

Berbicara didepan umum merupakan keterampilan yang dapat dipelajari, di praktikkan dan diperbaiki. Selain itu pelatihanpelatihan yang pernah diikuti juga akan menambah kemampuan.

3. Pengalaman

Keahlian dari banyak kompetensi memerlukan pengalaman mengorganisasi orang, komunikasi dihadapan kelompok, menyelesaikan masalah dan sebagainya. Pengalaman dapat dikembangkan berdasarkan lamanya waktu kerja dalam perusahaan atau organisasi.

4. Karakteristik Kepribadian 
Orang merespon dan berinteraksi dengan kekuatan dan lingkungan sekitarnya.

5. Motivasi

Motivasi merupakan faktor dalam kompetensi dengan memberikan dorongan, apresiasi terhadap pekerjaan bawahan, memberikan pengakuan dan perhatian individual dari atasan dapat mempunyai pengaruh positif terhadap motivasi seorang bawahan.

6. Kemampuan Intelektual

Kecakapan dalam bekerjasama dan kemampuan dengan memberikan dorongan, apresiasi terhadap bawahan, memberikan pengakuan dan perhatian individual dari atasan dapat mempunyai pengaruh positif terhadap bawahan.

7. Budaya Organisasi

Budaya organisasi meliputi lingkungan kerja yang dapat mempengaruhi kompetensi sumber daya manusia.

\section{2) Insentif}

\section{a. Pengertian Insentif}

Menurut Yani (2012:145) insentif merupakan salah satu penghargaan yang dikaitkan dengan prestasi kerja. Semakin tinggi prestasi kerja, maka semakin tinggi juga insentif yang diberikan. Pemberian insentif yang diterima tidak dikaitkan dengan prestasi kerja, tetapi bersifat pribadi maka mereka akan merasakan adanya ketidakadilan dapat mempengaruhi perilaku.

\section{b. Tujuan Pemberian Insentif} Menurut Yani (2012:146) bahwa pemberian insentif memiliki tujuan tertentu yaitu:

Untuk memberikan penghargaan kepada karyawan yang telah berprestasi. $\checkmark \quad$ Untuk memberikan tanggung jawab dan dorongan kepada karyawan.

$\checkmark \quad$ Untuk menjamin bahwa karyawan akan memberikan usahanya untuk mencapai tujuan organisasi atau perusahaan.

$\checkmark$ Untuk mengetahui usaha karyawan melalui kinerja

$\checkmark \quad$ Untuk meningkatkan produktivitas kinerja individu maupun kelompok.

\section{c. Manfaat Insentif}

Menurut Kadarisman (2012:221) ada dua manfaat besar dari sistem pemberian insentif ini diantaranya:

$>\quad$ Para karyawan terdorong bekerja secara produktif karena apabila produktivitas kerja mereka berakibat pada keuntungan perusahaan, mereka akan memperoleh penghasilan tambahan.

Secara psikologis timbul rasa sepenanggungan dan seperasaan dengan pihak manajemen karena para karyawan diikutsertakan secara langsung dalam menikmati perusahaan meraih keuntungan.

\section{3) Kinerja Karyawan}

a. Pengertian Kinerja Karyawan

Menurut Mangkunegara (2013:67) pengertian kinerja adalah hasil kerja secara kualitas dan kuantitas yang dicapai oleh seorang karyawan dalam melaksanakan tugasnya sesuai dengan tanggung jawab yang diberikan kepadanya.

\section{b. Manfaat Penilaian Kinerja}

Menurut Sedarmayanti (2014:264) manfaat penilaian kinerja yaitu :

$\checkmark$ Meningkatkan prestasi kerja, dengan adanya penilaian, baik pimpinan maupun karyawan 
memperoleh umpan balik dan mereka dapat memperbaiki pekerjaannya.

Memberi kesempatan kerja yang adil, penilaian akurat dapat menjamin karyawan memperoleh kesempatan menempati sisi pekerjaan sesuai kemampuannya.

Kebutuhan pelatihan dan pengembangan, melalui penilaian kinerja terdeteksi karyawan yang kemampuannya rendah sehingga memungkinkan adanya program pelatihan untuk meningkatkan kemampuan mereka.

$\checkmark$ Penyesuaian kompensasi, melalui penilaian pimpinan dapat mengambil keputusan dalam menentukan perbaikan pemberian kompensasi, dan sebagainya.

$\checkmark \quad$ Keputusan promosi dan demosi, hasil penilaian kinerja dapat digunakan sebagai dasar pengambilan keputusan untuk mempromosikan atau mendemosikan karyawan.

$\checkmark \quad$ Mendiagnosis kesalahan desain pekerjaan, karena kinerja yang buruk merupakan suatu tanda kesalahan dalam desain pekerjaan.

Menilai proses rekrutmen dan seleksi, kinerja karyawan baru yang rendah dapat mencerminkan adanya penyimpangan proses rekrutmen dan seleksi.

\section{c. Indikator Kinerja Karyawan} Menurut Mangkunegara (2013:75) indikator-indikator kinerja karyawan adalah sebagai berikut:

$>$ Kualitas, seberapa baik seorang karyawan mengerjakan apa yang seharusnya dikerjakan.

$>\quad$ Kuantitas Kerja, seberapa lama seorang pegawai bekerja dalam satu harinya. Kuantitas kerja ini dapat dilihat dari kecepatan kerja setiap pegawai itu masingmasing.

Tanggung Jawab, kesadaran akan kewajiban melakukan pekerjaan dengan akurat atau tidak ada kesalahan.

Kerjasama, kesediaan pegawai untuk berpartisipasi dengan pegawai lain secara vertical dan horizontal baik didalam maupun diluar pekerjaan sehingga hasil pekerjaan akan semakin baik.

Inisiatif, inisiatif dari dalam diri anggota perusahaan untuk melakukan pekerjaan serta mengenai masalah dalam pekerjaan tanpa menunggu perintah dari atasan atau menunjukkan tanggung jawab dalam pekerjaan yang sudah kewajiban seorang pegawai.

\section{4) Penelitian Terdahulu}

a. Pengaruh Kompetensi dan Insentif Terhadap Kinerja

Menurut Santoso (2016:67) dari hasil penelitian menunjukkan bahwa kompetensi dan insentif berpengaruh secara signifikan terhadap kinerja karyawan. Kompetensi secara parsial berpengaruh terhadap kinerja karyawan. Dan Insentif juga secara parsial berpengaruh terhadap kinerja karyawan pada PG. Madukismo Yogyakarta.

\section{b. Pengaruh Kompetensi dan Lingkungan Kerja Terhadap Kinerja \\ Menurut hasil penelitian yang} dilakukan Basori, Prahiawan, dan Daenulhay (2017:154) menunjukkan bahwa kompetensi dan lingkungan kerja secara bersama-sama tidak berpengaruh terhadap kinerja karyawan. Kompetensi Secara parsial tidak berpengaruh terhadap kinerja. 
Dan lingkungan kerja secara parsial tidak berpengaruh terhadap kinerja karyawan PT. Krakatau Bandar Samudera

\section{c. Pengaruh Insentif Terhadap Kinerja \\ Menurut Lestari (2013:57) dari} hasil penelitian menunjukkan bahwa insentif secara stimultan tidak berpengaruh terhadap kinerja karyawan. Insentif secara parsial tidak berpengaruh terhadap kinerja karyawan PT. PLN (Persero) Penyaluran dan Pusat Pengaturan Beban (P3B) Sumatera UPT Palembang.

\section{5) Kerangka Pemikiran}

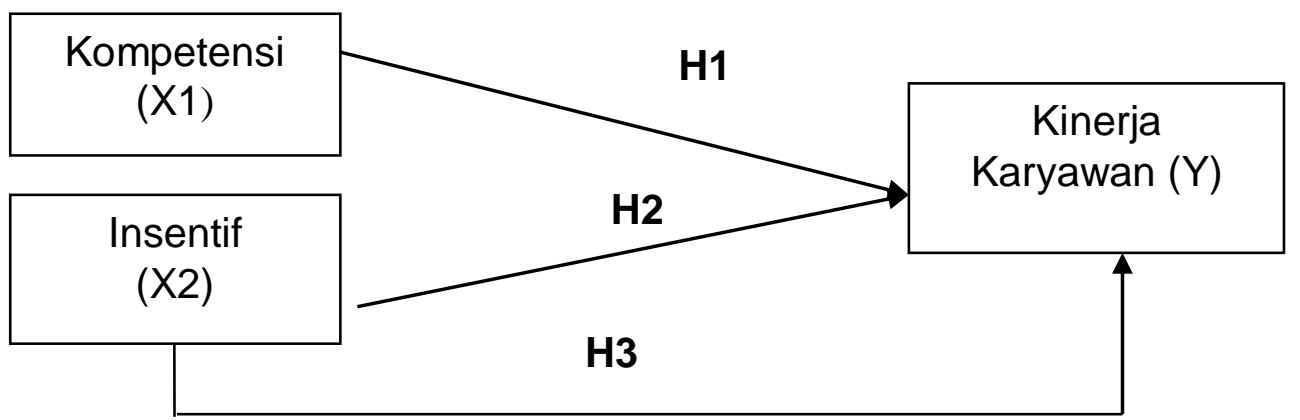

6) Hipotesis Penelitian

Menurut Sugiyono (2017:64) hipotesis merupakan jawaban sementara terhadap rumusan masalah penelitian, dimana rumusan masalah penelitian dinyatakan dalam bentuk pertanyaan. Dari kerangka pemikiran dan teori yang telah dikemukakan diatas, maka dapat diambil dugaan sementara atau hipotesis sebagai berikut:

$\mathrm{H}_{1}$ : Diduga kompetensi memberi pengaruh yang signifikan terhadap kinerja karyawan pada PT. Hijau Lestari Raya Fibreboard Pematang Palas.

$\mathrm{H}_{2}$ : Diduga insentif memberi pengaruh yang signifikan terhadap kinerja karyawan pada PT. Hijau Lestari Raya Fibreboard Pematang Palas.

$\mathrm{H}_{3}$ : Diduga kompetensi dan insentif secara simultan memberi pengaruh yang signifikan terhadap kinerja karyawan pada
PT. Hijau Lestari Raya Fibreboard Pematang Palas.

\section{METODE PENELITIAN}

1) Variabel Penelitian

Menurut Sugiyono (2017:38), mendefinisikan variabel penelitian adalah segala sesuatu yang berbentuk apa saja yang ditetapkan oleh peneliti untuk dipelajari sehingga diperoleh informasi tentang hal tersebut, kemudian ditarik kesimpulannya.

Sugiyono (2017:38), menyatakan dalam penelitian ini ada dua variabel diteliti yaitu variabel bebas dan variabel terikat:

a) Variabel bebas

Variabel bebas (independent) adalah variabel yang dipengaruhi atau yang menjadi sebagai perubahannya atau timbulnya variabel dependen (terikat). Dalam penelitian ini variabel bebas adalah Kompetensi (X1) dan Insentif (X2). 
b) Variabel terikat

Variabel terikat (Dependent)

atau yang menjadi akibat, karena adanya variabel bebas, dalam hal adalah variabel yang dipengaruhi ini variabel terikat adalah Kinerja Karyawan $(\mathrm{Y})$.

\section{2) Definisi Operasional Variabel}

Tabel Definisi Operasional Variabel

\begin{tabular}{|c|c|c|c|c|}
\hline No & Variabel & Definisi Variabel & Indikator & $\begin{array}{l}\text { Butir } \\
\text { soal }\end{array}$ \\
\hline 1. & $\begin{array}{l}\text { Kinerja } \\
\text { Karyawan } \\
\text { (Y) }\end{array}$ & $\begin{array}{l}\text { kinerja adalah hasil kerja } \\
\text { secara kualitas dan } \\
\text { kuantitas yang dicapai oleh } \\
\text { seorang karyawan dalam } \\
\text { melaksanakan tugasnya } \\
\text { sesuai dengan tanggung } \\
\text { jawab yang diberikan } \\
\text { kepadanya. } \\
\text { (Mangkunegara, 2013:67) }\end{array}$ & $\begin{array}{l}\text { 1. Kualitas } \\
\text { 2. Kuantitas } \\
\text { 3. Tanggung jawab } \\
\text { 4. Kerjasama } \\
\text { 5. Inisiatif } \\
\\
\text { (Mangkunegara, } \\
\text { 2013:75) }\end{array}$ & $\begin{array}{l}1,2 \\
3,4 \\
5,6 \\
7,8 \\
9,10\end{array}$ \\
\hline 2. & $\begin{array}{l}\text { Kompetensi } \\
\text { (X1) }\end{array}$ & $\begin{array}{l}\text { Kompetensi adalah segala } \\
\text { bentuk sikap, motif, } \\
\text { keterampilan, pengetahuan } \\
\text { perilaku atau karakteristik } \\
\text { pribadi lain yang penting un } \\
\text { tuk melaksanakan } \\
\text { pekerjaan sehingga dapat } \\
\text { membedakan } \\
\text { antara kinerja rata rata deng } \\
\text { an kinerja superior. } \\
\text { (Wibowo, 2017:283) }\end{array}$ & $\begin{array}{l}\text { 1.Keyakinan dan } \\
\text { nilai-nilai } \\
\text { 2.Keterampilan } \\
\text { 3.Pengalaman } \\
\text { 4.Karakteristik } \\
\text { kepribadian } \\
\text { 5.Motivasi } \\
\text { 6.Kemampuan } \\
\text { intelektual } \\
\text { 7.Budaya organisasi } \\
\\
\text { (Wibowo, 2014:283) }\end{array}$ & $\begin{array}{l}1,2 \\
3,4 \\
5 \\
6 \\
7 \\
8,9 \\
10\end{array}$ \\
\hline 3. & $\begin{array}{l}\text { Insentif } \\
\text { (X2) }\end{array}$ & $\begin{array}{l}\text { Insentif merupakan sesuatu } \\
\text { yang merangsang minat } \\
\text { untuk bekerja. } \\
\begin{array}{ll}\text { (Suwatno dan Priansa, } \\
2011: 234)\end{array}\end{array}$ & $\begin{array}{l}\text { 1. Bonus } \\
\text { 2. Komisi } \\
\text { 3.Pembagian Laba } \\
\text { 4. Kompensasi } \\
\text { 5. Piagam } \\
\\
\text { (Suwatno dan Priansa, } \\
2011: 236)\end{array}$ & $\begin{array}{l}1,2 \\
3,4 \\
5,6 \\
7,8 \\
9,10\end{array}$ \\
\hline
\end{tabular}

3) Populasi dan Sampel

a) Populasi Penelitian

Sugiyono (2017:80) populasi adalah wilayah generalisasi yang terdiri atas objek /subjek yang mempunyai kualitas dan karakteristik tertentu yang ditetapkan oleh peneliti untuk dipelajari dan kemudian ditarik kesimpulannya.

Populasi dalam penelitian ini adalah seluruh karyawan pada PT. Hijau Lestari Raya Fibreboard Pematang Palas yang berjumlah 210 orang. 


\section{b) Sampel}

Sugiyono (2017:81) sampel adalah bagian dari jumlah dan karakteristik yang dimiliki oleh populasi tersebut. Bila populasi besar dan penelitian tidak mungkin mempelajari semua yang ada populasi.

Sampel digunakan sebagai ukuran sampel dimana ukuran sampel merupakan suatu langkah untuk mengetahui besarnya sampel yang akan diambil. Kemudian besar sampel tersebut diukur secara statistika ataupun estimasi penelitian.

Salah satu metode yang digunakan untuk menentukan jumlah sampel adalah rumus Slovin, Sebagai berikut :

$$
n=\frac{N}{1+N \cdot e^{2}}
$$

Keterangan:

$\mathrm{N}$ : jumlah populasi

$\mathrm{n}$ : jumlah sampel

e : Kesalahan pengambilan sampel yang diinginkan $10 \%$

$n=\frac{N}{1+N \cdot e^{2}}=\frac{210}{1+210.10 \% \%^{2}}$

$n=\frac{210}{1+210 \times 0,01}$

$n=\frac{210}{1+2,1}$

$n=\frac{210}{3,1}=67,7419$ dibulatkan menjadi 68 orang.

\section{4) Metode Penelitian}

Sugiyono (2017:224) bahwa jenis data adalah macam-macam fakta yang muncul dilapangan akibat dari proses penelitian. Jenis data yang digunakan dalam penelitian ini adalah data kuantitatif, yaitu data yang di ukur dalam suatu skala numeric

\section{5) Sumber Data}

Menurut Sugiyono (2017:225)

Sumber data di bagi menjadi dua yaitu: $\checkmark$ Data Primer adalah data yang diperoleh secara langsung meliputi dokumen-dokumen perusahaan berupa sejarah perkembangan perusahaan, struktur organisasi dan lain lain yang berhubungan dengan penelitian.

$\checkmark$ Data Sekunder adalah data yang diperlukan untuk mendukung hasil penelitian berdasar dari literature, artikel dan berbagai sumber daya lainnya yang berhubungan dengan penelitian.

\section{6) Teknik Pengumpulan Data}

Menurut Sugiyono (2017:194), teknik pengumpulan data merupakan langkah yang paling utama dalam penelitian, karena tujuan utama dari penelitian adalah mendapatkan data. Teknik pengumpulan data yang digunakan dalam penelitian ini adalah sebagai berikut: Pendekatan Wawancara dan Kuisioner.

\section{7) Teknik Analisis Data}

Teknik analisis data dalam penelitian ini adalah teknik analisis regresi linear sederhana, regresi linear berganda, koefisien korelasi dan koefisien determinasi menggunakan alat bantu olah data untuk memecahkan masalah pengaruh variabel independen dan variabel dependen yaitu dengan menggunakan olah data SPSS versi 22.

\section{8) Uji Asumsi Klasik}

Menurut Priyatno (2014:93), uji penyimpangan asumsi klasik digunakan untuk mengetahui ada tidaknya normalitas, multikolinieritas, autokorelasi dan heteroskedastisitas dalam model regresi.

\section{9) Analisis Regresi Sederhana}

Menurut Sugiyono (2017:188), analisis regresi linier sederhana 
digunakan untuk mengetahui pengaruh atau hubungan secara linier satu variabel independen dengan satu variabel dependen

\section{0) Analisis Regresi Berganda}

Menurut Sugiyono (2017:277), analisis regresi linier berganda adalah analisis yang digunakan untuk mengetahui pengaruh atau hubungan secara linier antara dua atau lebih variabel independen dengan satu variabel dependen yang digunakan untuk memprediksi suatu nilai variabel dependen berdasarkan variabel independen. Untuk menentukan tingkat pengaruh antara variabel independen dengan variabel dependen dalam penelitian ini digunakan analisis regresi berganda untuk mengetahui pengaruh kompetensi dan insentif terhadap kinerja karyawan. Dalam penelitian ini untuk menganalisis koefisien korelasi, koefisien determinasi $\left(r^{2}\right)$, uji $t$ (parsial), uji $f$ (simultan)

\section{HASIL PENELITIAN \\ 1) Hasil Uji Validitas}

Hasil penelitian yang valid yaitu bila terdapat kesamaan antara data yang terkumpul dengan data yang diteliti. Untuk menguji apakah suatu data setiap butir valid atau tidaknya ditentukan dengan cara mengkorelasikan skor butir dengan skor total, uji validitas dilakukan untuk mengetahui tingkat ketepatan instrumen yang digunakan pada penelitian.

Tabel Hasil Uji Validitas Kompetensi

\begin{tabular}{|c|c|c|c|c|c|}
\hline No & Item Pertanyaan & $\mathbf{r}_{\text {hitung }}$ & $\mathbf{r}_{\text {tabel }}$ & Kriteria & Keterangan \\
\hline 1 & Item 1 & 0,386 & 0,238 & $r_{\text {hitung }}>r_{\text {tabel }}$ & Valid \\
\hline 2 & Item 2 & 0,572 & 0,238 & $r_{\text {hitung }}>r_{\text {tabel }}$ & Valid \\
\hline 3 & Item 3 & 0,515 & 0,238 & $r_{\text {hitung }}>r_{\text {tabel }}$ & Valid \\
\hline 4 & Item 4 & 0,358 & 0,238 & $r_{\text {hitung }}>r_{\text {tabel }}$ & Valid \\
\hline 5 & Item 5 & 0,457 & 0,238 & $r_{\text {hitung }}>r_{\text {tabel }}$ & Valid \\
\hline 6 & Item 6 & 0,531 & 0,238 & $r_{\text {hitung }}>r_{\text {tabel }}$ & Valid \\
\hline 7 & Item 7 & 0,393 & 0,238 & $r_{\text {hitung }}>r_{\text {tabel }}$ & Valid \\
\hline 8 & Item 8 & 0,270 & 0,238 & $r_{\text {hitung }}>r_{\text {tabel }}$ & Valid \\
\hline 9 & Item 9 & 0,374 & 0,238 & $r_{\text {hitung }}>r_{\text {tabel }}$ & Valid \\
\hline 10 & Item 10 & 0,540 & 0,238 & $r_{\text {hitung }}>r_{\text {tabel }}$ & Valid \\
\hline
\end{tabular}

Sumber : SPSS for windows versi 22, 2019

Dari tabel diatas dapat diketahui bahwa semua item pertanyaan valid pada variabel Kompetensi karena seluruh nilai $r_{\text {hitung }}>r_{\text {tabel. }}$ jadi dapat disimpulkan semua item pertanyaan variabel kompetensi adalah valid.

Tabel Hasil Uji Validitas Insentif

\begin{tabular}{|c|c|c|c|c|c|}
\hline No & Item Pertanyaan & $\mathbf{r}_{\text {hitung }}$ & $\mathbf{r}_{\text {tabel }}$ & Kriteria & Keterangan \\
\hline 1 & Item 1 & 0,568 & 0,238 & $r_{\text {hitung }}>r_{\text {tabel }}$ & Valid \\
\hline 2 & Item 2 & 0,660 & 0,238 & $r_{\text {hitung }}>r_{\text {tabel }}$ & Valid \\
\hline 3 & Item 3 & 0,750 & 0,238 & $r_{\text {hitung }}>r_{\text {tabel }}$ & Valid \\
\hline 4 & Item 4 & 0,348 & 0,238 & $r_{\text {hitung }}>r_{\text {tabel }}$ & Valid \\
\hline
\end{tabular}




\begin{tabular}{|c|c|c|c|c|c|}
\hline 5 & Item 5 & 0,556 & 0,238 & $r_{\text {hitung }}>r_{\text {tabel }}$ & Valid \\
\hline 6 & Item 6 & 0,679 & 0,238 & $r_{\text {hitung }}>r_{\text {tabel }}$ & Valid \\
\hline 7 & Item 7 & 0,520 & 0,238 & $r_{\text {hitung }}>r_{\text {tabel }}$ & Valid \\
\hline 8 & Item 8 & 0,502 & 0,238 & $r_{\text {hitung }}>r_{\text {tabel }}$ & Valid \\
\hline 9 & Item 9 & 0,542 & 0,238 & $r_{\text {hitung }}>r_{\text {tabel }}$ & Valid \\
\hline 10 & Item 10 & 0,630 & 0,238 & $r_{\text {hitung }}>r_{\text {tabel }}$ & Valid \\
\hline
\end{tabular}

Sumber : SPSS for windows versi 22, 2019

Dari tabel diatas dapat diketahui bahwa semua item pertanyaan valid pada variabel insentif karena seluruh nilai $r_{\text {hitung }}>r_{\text {tabel. }}$ Jadi dapat disimpulkan semua item pertanyaan variabel insentif adalah valid.

Tabel Hasil Uji Validitas Kinerja Karyawan

\begin{tabular}{|c|c|c|c|c|c|}
\hline No & Item Pertanyaan & $\mathbf{r}_{\text {hitung }}$ & $\mathbf{r}_{\text {tabel }}$ & Kriteria & Keterangan \\
\hline 1 & Item 1 & 0,466 & 0,238 & $r_{\text {hitung }}>r_{\text {tabel }}$ & Valid \\
\hline 2 & Item 2 & 0,458 & 0,238 & $r_{\text {hitung }}>r_{\text {tabel }}$ & Valid \\
\hline 3 & Item 3 & 0,395 & 0,238 & $r_{\text {hitung }}>r_{\text {tabel }}$ & Valid \\
\hline 4 & Item 4 & 0,410 & 0,238 & $r_{\text {hitung }}>r_{\text {tabel }}$ & Valid \\
\hline 5 & Item 5 & 0,519 & 0,238 & $r_{\text {hitung }}>r_{\text {tabel }}$ & Valid \\
\hline 6 & Item 6 & 0,239 & 0,238 & $r_{\text {hitung }}>r_{\text {tabel }}$ & Valid \\
\hline 7 & Item 7 & 0,281 & 0,238 & $r_{\text {hitung }}>r_{\text {tabel }}$ & Valid \\
\hline 8 & Item 8 & 0,360 & 0,238 & $r_{\text {hitung }}>r_{\text {tabel }}$ & Valid \\
\hline 9 & Item 9 & 0,494 & 0,238 & $r_{\text {hitung }}>r_{\text {tabel }}$ & Valid \\
\hline 10 & Item 10 & 0,558 & 0,238 & $r_{\text {hitung }}>r_{\text {tabel }}$ & Valid \\
\hline
\end{tabular}

Sumber : SPSS for windows versi 22, 2019

Dari tabel diatas dapat diketahui bahwa semua item pertanyaan valid pada variabel kinerja karyawan karena seluruh nilai $r_{\text {hitung }}>r_{\text {tabel }}$. Jadi dapat disimpulkan semua item pertanyaan variabel kinerja karyawan adalah valid.

\section{2) Hasil Uji Reliabilitas}

Menurut Sujarweni (2014:192) bahwa uji reliabilitas bahwa uji realibilitas merupakan ukuran suatu kestabilan dan konsisten responden dalam menjawab hal yang berkaitan dengan kontruk pertanyaan yang merupakan dimensi suatu variabel dan disusun dalam bentuk kuisioner. Uji ini dilakukan secara bersama-sama terhadap seluruh butir pertanyaan. Jika nilai Alpha > 0,60 maka reliable.

Tabel Uji Realiabilitas Kompetensi Reliability Statistics

\begin{tabular}{|c|c|}
\hline Cronbach's Alpha & N of Items \\
\hline ,685 & 10 \\
\hline \multicolumn{2}{|c|}{ Sumber : SPSS windows versi 22,2019 }
\end{tabular}

Dari tabel diatas dapat diketahui bahwa nilai Cronbach Alpha sebesar 0,685 > dari 0,60. Karena Cronbach Alpha Cronbach Alpha > 0,60, maka alat ukur dalam penelitian ini adalah realiabel (dapat dipercaya) dan dapat digunakan sebagai alat ukur dalam analisis selanjutnya. 
Tabel Uji Realiabilitas Insentif Reliability Statistics

\begin{tabular}{|c|c|}
\hline Cronbach's Alpha & N of Items \\
\hline, 739 & 10 \\
\hline
\end{tabular}

Sumber : SPSS windows versi 22, 2019

Dari tabel diatas dapat diketahui bahwa nilai Cronbach Alpha sebesar $0,739>$ dari 0,60. Karena Cronbach Alpha Cronbach Alpha > 0,60, maka alat ukur dalam penelitian ini adalah realiabel (dapat dipercaya) dan dapat digunakan sebagai alat ukur dalam analisis selanjutnya.

Reliability Statistics

\section{Tabel Uji Realiabilitas Kinerja Karyawan}

\begin{tabular}{|c|c|}
\hline Cronbach's Alpha & N of Items \\
\hline, 695 & 10 \\
\hline
\end{tabular}

Sumber : SPSS windows versi 22, 2019

Dari tabel diatas dapat diketahui bahwa nilai Cronbach Alpha sebesar $0,695>$ dari 0,60. Karena Cronbach Alpha Cronbach Alpha $>0,60$, maka alat ukur dalam penelitian ini adalah realiabel (dapat dipercaya) dan dapat digunakan sebagai alat ukur dalam analisis selanjutnya.

\section{3) Hasil Uji Asumsi Klasik \\ a) Uji Normalitas}

Uji normalitas data merupakan syarat pokok yang harus dipenuhi dalam analisis parametrik. Normalitas data merupakan hal yang penting karena dengan data yang terdistribusi normal, maka data tersebut dianggap dapat mewakili populasi.

Dalam penelitian normalitas data diuji menggunakan uji one sample kolmogorov-smirnov test. Dalam uji one sample kolmogorov-smirnov test, variabel-variabel yang mempunyai asympototic signifinance (2-tailed) diatas tingkat signifikan 0,05 maka diartikan bahwa variabel-variabel tersebut memiliki distribusi normal dan sebaliknya. Pengambilan keputusan normal atau tidaknya data sebagai berikut :

1. Jika sig $<0,05$ distribusi data adalah tidak normal

2. Jika Sig >0,05 distribusi data adalah normal

Tabel Hasil Uji Normalitas

\begin{tabular}{|c|c|c|c|}
\hline Variabel & \multicolumn{2}{|c|}{ Sig (2-Tailed) > Alpha ( $\mathbf{\alpha})$} & Kesimpulan \\
\hline Kompetensi $\left(\mathrm{X}_{1}\right)$ & 0,763 & 0,05 & Normal \\
\hline Insentif $\left(\mathrm{X}_{2}\right)$ & 0,912 & 0,05 & Normal \\
\hline Kinerja Karyawan $(\mathrm{Y})$ & 0,362 & 0,05 & Normal \\
\hline
\end{tabular}

Sumber : SPSS windows versi 22, 2019

Pada tabel diatas terlihat bahwa masing-masing variabel penelitian yang terdiri dari Kompetensi dan Insentif Terhadap Kinerja Karyawan telah menghasilkan nilai asympsig (2tailed) lebih besar atau sama dengan alpha 0,05 (Signifikan > 0,05) sehingga dapat disimpulkan bahwa seluruh variabel penelitian yang digunakan telah berdistribusi normal. Dengan demikian tahapan pengolahan data lebih lanjut dapat segera dilaksanakan.

\section{b) Uji Multikolinearitas}

Uji multikolinieritas adalah keadaan dimana ada hubungan linear secara sempurna atau mendekati sempurna antara variabel independen dalam model regresi. Model regresi yang baik adalah tidak terjadinya 
Multikolinieritas. Uji Multikolinieritas bertujuan untuk menguji apakah model regresi ditemukan adanya kolerasi atas variabel bebas (Independen). Kriteria dari uji Multikolinieritas dapat dilihat dari nilai tolerance dan lawannya yaitu variance inflation factor. Kedua variabel ini menunjukkan setiap variabel independen manakah yang dijelaskan oleh variabel independen lainnya. Batasan umum yang digunakan adalah tolerance lebih dari 0,1 dan nilai VIF kurang dari 10 maka tidak terjadi multikolinieritas.

\section{Tabel Hasil Uji Multikolinearitas}

Coefficients $^{a}$

\begin{tabular}{|c|c|c|c|c|c|c|c|}
\hline \multirow[b]{2}{*}{ Model } & \multicolumn{2}{|c|}{$\begin{array}{c}\text { Unstandardized } \\
\text { Coefficients }\end{array}$} & \multirow{2}{*}{$\begin{array}{c}\text { Standardized } \\
\text { Coefficients } \\
\text { Beta }\end{array}$} & \multirow[b]{2}{*}{$\mathbf{T}$} & \multirow[b]{2}{*}{ Sig. } & \multicolumn{2}{|c|}{$\begin{array}{c}\text { Collinearity } \\
\text { Statistics }\end{array}$} \\
\hline & B & $\begin{array}{l}\text { Std. } \\
\text { Error }\end{array}$ & & & & Tolerance & VIF \\
\hline 1 (Constant) & 22,621 & 3,402 & & 6,650 &, 000 & & \\
\hline Kompetensi & ,300 & , 101 & ,351 & 2,976 & ,004 & 695 & 1,438 \\
\hline Insentif & 208 & ,072 & ,342 & 2,903 & ,005 & ,695 & 1,438 \\
\hline
\end{tabular}

a. Dependent Variable: Kinerja Karyawan

Sumber : SPSS windows versi 22, 2019

Berdasarkan tabel diatas, bahwa nilai tolerance variabel kompetensi dan Insentif 0,695 > 0,1 dan nilai VIF (Variance Inflation Factor) variabel kompetensi dan insentif 1,438 < 10 maka dapat disimpulkan tidak terjadi multikolinearitas.

\section{c) Uji Heteroskedastisitas}

Uji heteroskedastisitas adalah varian residual yang tidak sama pada semua pengamatan didalam model regresi. Regresi yang baik harusnya tidak terjadi Heteroskedastisitas.

Untuk menguji terjadinya heteroskedastisitas dilakukan dengan uji Glesjer dengan cara meregresikan antara variabel independen dengan nilai absolute residualnya. Jika nilai Sig $>0,05$ maka tidak terjadi masalah heteroskedastisitas, dan jika Sig $<0,05$ maka terjadi heteroskedastisitas.

Tabel Hasil Uji Heteroskedastisitas Coefficients $^{a}$

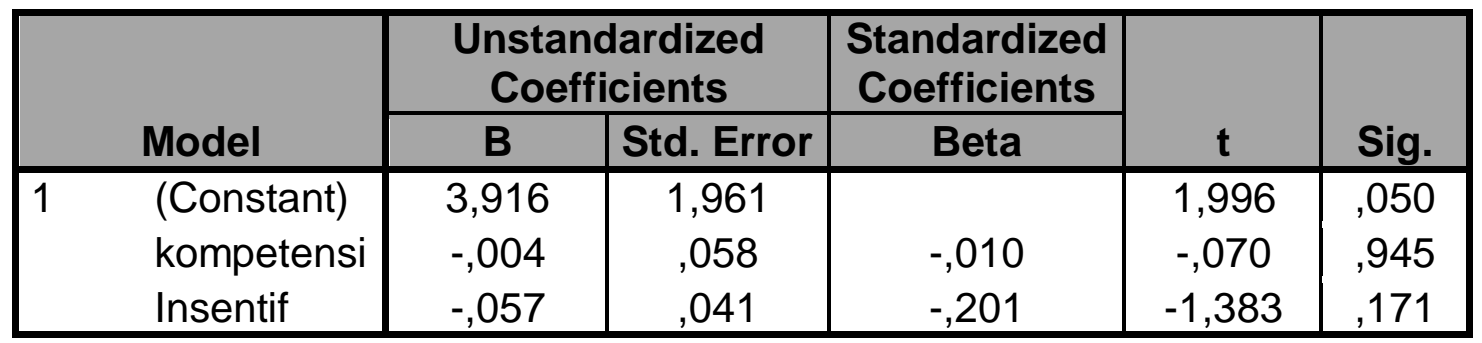

a. Dependent Variable: RES2

Sumber : SPSS windows versi 22, 2019

Dari tabel diatas, diketahui nilai signifikan untuk variabel kompetensi adalah 0,945 dan untuk variabel insentif adalah 0,171 . Karena nilai signifikan kedua variabel lebih besar dari 0,05 maka sesuai dengan tabel diatas diambil kesimpulan dalam uji glejser tidak terjadi gejala heteroskedastisitas dalam model regresi. 
4) Hasil Analisis Data

a) Hasil Analisis Regresi Linier Berganda

Analisis linear sederhana digunakan untuk mengetahui pengaruh atau hubungan secara linear antara suatu variabel independen dengan satu variabel dependen (Sugiyono, 2017:188).

Persamaan regresi dalam penelitian ini adalah untuk mengetahui seberapa pengaruh kinerja karyawan terhadap kompetensi dan insentif.

Tabel Hasil Regresi Linear Sederhana Kompetensi terhadap Kinerja Karyawan Coefficients $^{a}$

\begin{tabular}{|cc|c|c|c|c|c|}
\hline \multirow{2}{*}{ Model } & \multicolumn{2}{|c|}{$\begin{array}{c}\text { Unstandardized } \\
\text { Coefficients }\end{array}$} & $\begin{array}{c}\text { Standardized } \\
\text { Coefficients }\end{array}$ & & \\
\cline { 2 - 5 } & B & Std. Error & Beta & T & Sig. \\
\hline 1 & (Constant) & 24.362 & 3.532 & & 6.898 & .000 \\
& Kompetensi & .462 & .089 & .540 & 5.206 & .000 \\
\hline
\end{tabular}

a. Dependent Variable: kinerja

Sumber : SPSS windows versi 22, 2019

Berdasarkan tabel diatas, hasil regresi linier sederhana diperoleh nilai koefisien regresi untuk kompetensi $\left(X_{1}\right)$ sebesar 0,462 dan nilai konstanta 24,362. Berdasarkan nilai tersebut diperoleh persamaan regresi sederhana sebagai berikut $\mathrm{Y}=24,362+0,462 \mathrm{X}_{1}$ Artinya apabila kompetensi $\left(X_{1}\right)$ mengalami kenaikan 1 satuan, maka Kinerja Karyawan $(\mathrm{Y})$ mengalami kenaikan sebesar 0,462.

Tabel Hasil Regresi Linear Sederhana Insentif Terhadap Kinerja Karyawan Coefficients $^{a}$

\begin{tabular}{|c|c|c|c|c|c|c|}
\hline & \multirow[b]{2}{*}{ Model } & \multicolumn{2}{|c|}{$\begin{array}{l}\text { Unstandardized } \\
\text { Coefficients }\end{array}$} & \multirow{2}{*}{$\begin{array}{c}\begin{array}{c}\text { Standardized } \\
\text { Coefficients }\end{array} \\
\text { Beta }\end{array}$} & \multirow[b]{2}{*}{$t$} & \multirow[b]{2}{*}{ Sig. } \\
\hline & & B & Std. Error & & & \\
\hline & $\begin{array}{l}\text { (Constant) } \\
\text { insentif }\end{array}$ & $\begin{array}{l}29.925 \\
.326\end{array}$ & $\begin{array}{l}2.492 \\
.063\end{array}$ & .536 & $\begin{array}{l}12.008 \\
5.154\end{array}$ & $\begin{array}{l}.000 \\
.000\end{array}$ \\
\hline
\end{tabular}

a. Dependent Variable: kinerja

Sumber : SPSS windows versi 22, 2019

Berdasarkan tabel diatas, hasil regresi linier sederhana diperoleh nilai koefisien regresi untuk insentif $\left(\mathrm{X}_{2}\right)$ sebesar 0,326 dan nilai konstanta 29,925. Berdasarkan nilai tersebut diperoleh persamaan regresi sederhana sebagai berikut $Y=29,925+0,326 X_{2}$ Artinya apabila Insentif $\left(X_{2}\right)$ mengalami kenaikan 1 satuan, maka Kinerja Karyawan ( $\mathrm{Y}$ ) mengalami kenaikan sebesar 0,326.

\section{b) Hasil Analisis Regresi Linier Berganda}

Analisis regresi digunakan untuk memprediksi seberapa jauh perubahan variabel dependent, bila nilai variabel independent di ubah-ubah atau ditarikturunkan. Manfaat dari hasil analisis regresi adalah untuk membuat keputusan apakah naik dan menurunnya variabel dependent dapat dilakukan peningkatan variabel independent atau tidaknya. 
Analisis regresi linear berganda yaitu suatu analisis untuk melihat seberapa besar pengaruh variabel kompetensi dan insentif dalam membangun kinerja karyawan.

Tabel Hasil Uji Regresi Linier Berganda

\begin{tabular}{|c|c|c|c|c|c|c|}
\hline & \multirow[b]{2}{*}{ Model } & \multicolumn{2}{|c|}{$\begin{array}{l}\text { Unstandardized } \\
\text { Coefficients }\end{array}$} & \multirow{2}{*}{$\begin{array}{c}\begin{array}{c}\text { Standardized } \\
\text { Coefficients }\end{array} \\
\text { Beta }\end{array}$} & \multirow[b]{2}{*}{ t } & \multirow[b]{2}{*}{ Sig. } \\
\hline & & $\bar{B}$ & Std. Error & & & \\
\hline 1 & $\begin{array}{l}\text { (Constant) } \\
\text { Kompetensi } \\
\text { Insentif }\end{array}$ & $\begin{array}{c}22,621 \\
, 300 \\
, 208\end{array}$ & $\begin{array}{c}3,402 \\
, 101 \\
, 072\end{array}$ & $\begin{array}{l}\text { 351 } \\
\text { 342 }\end{array}$ & $\begin{array}{l}6,650 \\
2,976 \\
2,903\end{array}$ & $\begin{array}{l}, 000 \\
, 004 \\
, 005\end{array}$ \\
\hline
\end{tabular}

Sumber : SPSS windows versi 22, 2019

Berdasarkan hasil regresi linier berganda diperoleh nilai koefisien regresi untuk kompetensi $\left(\mathrm{X}_{1}\right)$ sebesar 0,300 dan nilai koefisien regresi untuk insentif $\left(X_{2}\right)$ sebesar 0,208 dan nilai konstanta 22,621. Berdasarkan nilai tersebut, maka diperoleh nilai persamaan regresi linea $r$ berganda $Y=22,621+0,300 X_{1}+$ $0,208 X_{2}$ Artinya apabila kompetensi $\left(X_{1}\right)$ mengalami kenaikan 1 satuan, maka Kinerja Karyawan (Y) mengalami kenaikan sebesar 0,300. Selanjutnya apabila insentif $\left(\mathrm{X}_{2}\right)$ mengalami kenaikan 1 satuan, maka nilai Kinerja Karyawan (Y) mengalami peningkatan sebesar 0,208.

\section{c) Hasil Analisis Koefisien Korelasi}

Analisis koefisien digunakan untuk membandingkan hasil pengukuran dua variabel yang berbeda agar dapat menentukan hasil hubungan antara variabel.

\section{Tabel Koefisien Korelasi Model Summary}

\begin{tabular}{|l|l|l|l|l|}
\hline Model & $\mathbf{R}$ & R Square & $\begin{array}{l}\text { Adjusted } \\
\text { R Square }\end{array}$ & $\begin{array}{l}\text { Std. Error of } \\
\text { the Estimate }\end{array}$ \\
\hline 1 &, $610^{\mathrm{a}}$ &, 372 &, 353 & 1,91564 \\
\hline
\end{tabular}

a. Predictors: (Constant), Insentif, kompetensi

b. Dependent variable: kinerja karyawan

Sumber : SPSS windows versi 22, 2019

Dari hasil tabel diatas, diketahui bahwa nilai koefisien korelasi (R) antara kompetensi dan insentif terhadap kinerja karyawan adalah sebesar 0,610. Sementara itu kriteria nilainya adalah sebagai berikut :

Tabel Interprestasi Koefisien Korelasi Nilai $r$

\begin{tabular}{|c|c|c|}
\hline No & Interval Koefisien & Tingkat Hubungan \\
\hline 1 & $0,80-1,00$ & Sangat Kuat \\
\hline 2 & $\mathbf{0 , 6 0 - 0 , 7 9}$ & Kuat \\
\hline 3 & $0,40-0,59$ & Sedang \\
\hline 4 & $0,20-0,39$ & Rendah \\
\hline 5 & $0,00-0,19$ & Sangat Rendah \\
\hline
\end{tabular}

Sumber : Sugiyono 2017 
Nilai koefisien korelasi $(R)$ yaitu sebesar 0,610, berarti berada pada range 0,60 - 0,79. Hal ini menunjukkan bahwa korelasi antara kompetensi $\left(X_{1}\right)$ dan insentif $\left(X_{2}\right)$ terhadap kinerja karyawan $(Y)$ adalah kuat.

\section{d) Hasil Koefisien Determinasi}

Koefisien determinasi $\left(R^{2}\right)$ pada intinya mengukur seberapa jauh kemampuan model dalam menerangkan variasi variabel dependen. Nilai koefisien determinasi adalah antara nol dan satu. Nilai $\mathrm{R}^{2}$ yang kecil berarti kemampuan variabel-variabel bebas (kompetensi dan insentif) dalam menjelaskan variasi variabel terikat (kinerja karyawan) amat terbatas. Begitu pula sebaliknya, nilai yang akan mendekati satu berarti variabel-variabel bebas memberikan hampir semua informasi yang dibutuhkan untuk memprediksi variasi variabel terikat.

\section{Tabel Hasil Uji Koefisien Determinasi}

Model Summary

\begin{tabular}{|l|l|l|l|l|}
\hline Model & $\mathbf{R}$ & $\mathbf{R}$ Square & $\begin{array}{l}\text { Adjusted } \\
\text { Square }\end{array}$ & $\begin{array}{l}\text { Std. Error of } \\
\text { the Estimate }\end{array}$ \\
\hline 1 &, $610^{\mathrm{a}}$ &, 372 &, 353 & 1,91564 \\
\hline
\end{tabular}

a. Predictors: (Constant), Insentif, kompetensi

b. Dependent variable: kinerja karyawan

Sumber : SPSS windows versi 22, 2019

Dari tabel diatas, dapat diketahui bahwa koefisien determinasi $R$ Square $\left(R^{2}\right)$ sebesar 0,372 atau $37,2 \%$ yang berarti bahwa kinerja karyawan dapat dijelaskan variabel kompetensi dan insentif sebesar $37,2 \%$ sedangkan sisanya (100\% - 37,2\%) hasilnya $62,8 \%$ dipengaruhi oleh faktor-faktor lain yang tidak diteliti dalam penelitian ini.

\section{5) Hasil Uji Hipotesis Penelitian a) Hasil Uji t}

Uji t digunakan untuk mengetahui apakah masing-masing variabel bebasnya secara sendiri-sendiri berpengaruh secara signifikan terhadap variabel terikat dimana jika sig > a $(0,05)$, maka $\mathrm{H}_{0}$ diterima dan $\mathrm{H}_{\mathrm{a}}$ ditolak dan sebaliknya jika sig $<\alpha$ $(0,05)$ maka $\mathrm{H}_{0}$ ditolak dan $\mathrm{H}_{\mathrm{a}}$ ditolak.

Cara pengujian hipotesis dengan kriteria penerimaan $\mathrm{H}_{0}$ adalah jika sig $>$ 0,05 maka $\mathrm{H}_{0}$ diterima dan $\mathrm{H}_{\mathrm{a}}$ ditolak dan jika sig $<0,05$ maka $\mathrm{H}_{0}$ ditolak dan $\mathrm{H}_{\mathrm{a}}$ diterima.

Tabel Hasil Uji t

\begin{tabular}{|cl|l|l|l|l|l|}
\hline \multirow{2}{*}{ Model } & \multicolumn{2}{|c|}{$\begin{array}{c}\text { Unstandardized } \\
\text { Coefficients }\end{array}$} & $\begin{array}{c}\text { Standardized } \\
\text { Coefficients }\end{array}$ & & \multirow{2}{*}{ Sig. } \\
\cline { 2 - 5 } & $\mathbf{B}$ & Std. Error & Beta & t & Sig. \\
\hline \multirow{2}{*}{1} & (Constant) & 22,621 & 3,402 & & 6,650 &, 000 \\
& Kompetensi &, 300 &, 101 &, 351 & 2,976 &, 004 \\
& Insentif &, 208 &, 072 &, 342 & 2,903 &, 005 \\
\hline
\end{tabular}

a. Dependent Variabel Kinerja Karyawan

Sumber : SPSS windows versi 22, 2019 
Uji t pada tabel diatas, untuk menguji pengaruh tiap variabel independent terhadap variabel dependent dengan membandingkan nilai signifikan dengan sig 0,05. Jika signifikan $<0,05$ maka variabel tersebut berpengaruh secara signifikan.

Nilai uji t dibandingkan dengan taraf signifikan sebesar 0,05 dan jumlah data sebanyak 68 . Sehingga uji t pada tabel diatas adalah:

Kompetensi $\left(X_{1}\right)=0,004<0,05$.

Artinya secara parsial ada pengaruh yang signifikan antara Kompetensi terhadap Kinerja Karyawan pada PT. Hijau Lestari Raya Fibreboard Pematang Palas.
Insentif $\left(X_{2}\right)=0,005<0,05$. Artinya secara parsial ada pengaruh yang signifikan antara Insentif terhadap Kinerja Karyawan pada PT. Hijau Lestari Raya Fibreboard Pematang Palas.

\section{b) Hasil Uji F}

Uji $F$ berfungsi untuk mengetahui signifikan pengaruh atau hubungan antara semua variabel bebas dan variabel terikat.

Penerimaan atau penolakan $\mathrm{H}_{0}$ dapat dilihat dari nilai probabilitas (sig F) dimana jika sig $<\alpha(0,05)$ maka $\mathrm{H}_{0}$ ditolak dan $\mathrm{H}_{a}$ diterima dan jika sig $>\alpha$ $(0,05)$ maka $\mathrm{H}_{0}$ diterima dan $\mathrm{H}_{\mathrm{a}}$ ditolak.

Tabel Hasil Uji F

ANOVA $^{\mathrm{a}}$

\begin{tabular}{|ll|l|l|l|l|l|}
\hline \multicolumn{1}{|l|}{ Model } & $\begin{array}{l}\text { Sum of } \\
\text { Squares }\end{array}$ & Df & $\begin{array}{l}\text { Mean } \\
\text { Square }\end{array}$ & F & Sig. \\
\hline $1 \quad$ Regression & 141,588 & 2 & 70,794 & 19,292 &, $000^{\mathrm{b}}$ \\
Residual & 238,530 & 65 & 3,670 & & \\
Total & 380,118 & 67 & & & \\
\hline
\end{tabular}

a. Dependent Variable: Kinerja Karyawan

b. Predictors: (Constant), Insentif, Kompetensi

Sumber : SPSS windows versi 22, 2019

Dari hasil uji $\mathrm{F}$ diatas diperoleh nilai sig $0,000<0,05$. Maka hipotesis (Ho) ditolak dan ( $\mathrm{Ha})$ diterima. Hal ini menunjukkan bahwa ada pengaruh signifikan antara kompetensi dan Insentif secara bersama-sama terhadap Kinerja Karyawan Pada PT. Hijau Lestari Raya Fibreboard Pematang Palas.

\section{E. Pembahasan}

1) Pengaruh Kompetensi Pada PT. Hijau Lestari Raya Fibreboard Pematang Palas.

Dari hasil pengujian hipotesis (uji

t) secara parsial antara variabel
Kompetensi $\left(\mathrm{X}_{1}\right)$ terhadap variabel Kinerja Karyawan $(Y)$ diperoleh nilai sig $0,004<0,05$ maka dapat disimpulkan bahwa secara parsial ada pengaruh yang signifikan antara kompetensi terhadap kinerja karyawan pada PT. Hijau Lestari Raya Fibreboard Pematang Palas.

Hasil Penelitian ini bertentangan dengan hasil penelitian Basori, Prahiawan, dan Daenulhay (2017) yang menyatakan bahwa secara stimultan kompetensi dan lingukungan kerja terhadap kinerja karyawan pada suatu perusahaan/instansi tidak ada pengaruh yang signifikan antara kompetensi dan lingkungan terhadap 
kinerja karyawan. Secara parsial kompetensi tidak berpengaruh terhadap kinerja. Dan Secara parsial lingkungan kerja tidak berpengaruh terhadap kinerja karyawan.

Hasil penelitian ini berkesesuaian dengan menurut Sedarmayanti (2017:211) kompetensi merupakan kemampuan yang diharapkan dan menghasilkan yang terbaik. Tidak semua pegawai memiliki kompetensi hanya sebagian yang memiliki kinerja yang baik dan tinggi yang mempunyai kompetensi. Namun apabila kemampuan itu tidak dapat dikembangkan dengan baik maka akan berdampak buruk sehingga menimbulkan kinerja yang kurang maksimal.

Berdasarkan penelitian yang
penulis lakukan penelitian ini menunjukkan bahwa kinerja karyawan memiliki hubungan terhadap kompetensi karena jika karyawan bisa mengembangkan kemampuan dan keterampilannya, maka akan menghasilkan kinerja yang baik.

Berdasarkan teori dalam penelitian ini disarankan kepada pihak manajemen perusahaan harus senantiasa melakukan pelatihan dan pengembangan kompetensi kepada karyawannya, agar dapat meningkatkan kemampuan atau keterampilan karyawan agar menghasilkan kinerja yang baik.

\section{2) Pengaruh Insentif Terhadap Kinerja Karyawan Pada PT. Hijau Lestari Raya Fibreboard Pematang Palas}

Hasil hipotesis (uji t) secara parsial antara variabel Insentif $\left(X_{2}\right)$ terhadap variabel Kinerja Karyawan (Y) diperoleh nilai sig 0,005 $<0,05$ maka dapat disimpulkan bahwa secara parsial ada pengaruh yang signifikan antara Insentif terhadap kinerja karyawan pada PT. Hijau Lestari Raya
Fibreboard Pematang Palas.

Hasil Penelitian ini bertentangan dengan hasil penelitian Lestari (2013) yang menyatakan bahwa secara parsial insentif terhadap kinerja karyawan pada suatu perusahaan/instansi tidak ada pengaruh yang signifikan antara insentif terhadap kinerja karyawan.

Hasil penelitian ini berkesesuaian dengan pendapat ahli Yani (2012:145) insentif merupakan salah satu penghargaan yang dikaitkan dengan prestasi kerja. Semakin tinggi prestasi kerja, semakin tinggi juga insentif yang diberikan. Pemberian insentif yang diterima dikaitkan dengan prestasi kerja, tetapi bersifat pribadi maka mereka akan merasakan adanya ketidakadilan dapat mempengaruhi perilaku.

Berdasarkan penelitian yang penulis lakukan penelitian ini menunjukkan bahwa kinerja karyawan memiliki hubungan terhadap insentif karena jika karyawan bisa berprestasi, maka semakin tinggi pula insentif yang diberikan, Karena jika karyawan berprestasi berarti kinerja yang dilakukan sudah maksimal atau baik.

Berdasarkan teori dalam penelitian ini disarankan kepada pihak manajemen perusahaan harus senantiasa adil dalam pemberian insentif, agar tidak ada kecemburuan antar karyawan. Walaupun insentif hanya diberikan kepada karyawan yang memiliki kinerja yang baik.

\section{3) Pengaruh Kompetensi dan Insentif Terhadap Kinerja Karyawan Pada PT. Hijau Lestari Raya Fibreboard Pematang Palas \\ Dari hasil pengujian hipotesis (uji F) secara bersama-sama antara kompetensi $\left(\mathrm{X}_{1}\right)$ dan insentif $\left(\mathrm{X}_{2}\right)$ terhadap kinerja karyawan (Y) diperoleh nilai hasil uji $F$ diatas}


diperoleh nilai sig 0,000 $<0,05$. Maka hipotesis alternative $(\mathrm{Ha})$ diterima dan hipotesis nol $(\mathrm{Ho})$ ditolak. Maka dapat disimpulkan bahwa secara bersamasama ada pengaruh yang signifikan antara kompetensi dan insentif terhadap kinerja karyawan pada PT. Hijau Lestari Raya Fibreboard Pematang Palas.

Hasil Penelitian ini sejalan dengan hasil penelitian Santoso (2016) yang menyatakan secara bersamasama kompetensi dan insentif terhadap kinerja karyawan pada suatu perusahaan/instansi bahwa ada pengaruh yang signifikan antara kompetensi dan insentif terhadap kinerja karyawan.

Hasil penelitian berkesesuaian dengan pendapat Mangkunegara (2013:67) kinerja adalah hasil kerja secara kualitas dan kuantitas yang dicapai oleh seseorang karyawan dalam melaksanakan tugasnya sesuai dengan tanggung jawab yang diberikan kepadanya.

Berdasarkan penelitian yang penulis lakukan penelitian ini menunjukkan bahwa kinerja karyawan memiliki hubungan terhadap kompetensi dan insentif. Karena jika karyawan bisa mengembangkan kemampuan dan keterampilannya, maka akan menghasilkan kinerja yang baik dan semakin baik kinerja karyawan maka akan memiliki prestasi dalam bekerja semakin tinggi prestasi maka semakin tinggi juga insentif yang didapatkan.

Berdasarkan teori dalam penelitian ini disarankan kepada pihak manajemen perusahaan harus senantiasa melakukan pelatihan dan pengembangan kepada karyawannya, agar dapat meningkatkan kemampuan atau keterampilan karyawan agar kinerjanya baik dan maksimal. Selain melakukan pelatihan hendaknya manajemen perusahaan memberikan insentif kepada seluruh karyawan agar karyawan bersemangat dalam melakukan pekerjaan sehingga kinerja karyawan meningkat, karena jika insentif diberikan keseluruh karyawan mereka akan merasa ada keadilan, dan mencegah kecemburuan sosial antar karyawan.

\section{F. KESIMPULAN DAN SARAN}

1) Kesimpulan

Berdasarkan analisis data dan pembahasan yang telah dijabarkan, maka dalam penelitian ini diperoleh kesimpulan sebagai berikut :

$\checkmark$ Berdasarkan hasil pengujian hipotesis (uji t) secara parsial antara variabel kompetensi $\left(\mathrm{X}_{1}\right)$ terhadap variabel kinerja karyawan $(\mathrm{Y})$ di peroleh nilai sig $0,004<$ signifikan 0,05. Maka dapat disimpulkan bahwa secara parsial ada pengaruh yang signifikan antara Kompetensi terhadap Kinerja Karyawan pada PT. Hijau Lestari Raya Fibreboard Pematang Palas.

$\checkmark$ Berdasarkan hasil pengujian hipotesis (uji t) secara parsial antara variabel Insentif $\left(\mathrm{X}_{2}\right)$ terhadap variabel Kinerja Karyawan (Y) di peroleh nilai sig 0,005 < signifikan 0,05. Maka dapat disimpulkan bahwa secara parsial ada pengaruh yang signifikan antara Insentif terhadap Kinerja Karyawan pada PT. Hijau Lestari Raya Fibreboard Pematang Palas.

$\checkmark \quad$ Berdasarkan pengujian hipotesis (uji F) secara bersama-sama antara variabel Kompetensi $\left(X_{1}\right)$ dan variabel Insentif $\left(X_{2}\right)$ terhadap variabel Kinerja Karyawan $(Y)$ diperoleh nilai sig $0,000<0,05$. Maka hipotesis alternative $(\mathrm{Ha})$ diterima dan hipotesis nol (Ho) ditolak. Hal ini menunjukkan bahwa ada 
pengaruh signifikan antara kompetensi dan insentif secara bersama-sama terhadap kinerja karyawan pada PT. Hijau Lestari Raya Fibreboard Pematang Palas.

\section{2) Saran}

Sehubungan dengan kesimpulan di atas yang telah diuraikan, maka penulis memberikan saran sebagai bahan masukan bagi PT. Hijau Lestari Raya Fibreboard Pematang Palas penulis ajukan berkaitan dengan penelitian, mudah-mudahan dapat di ambil manfaatnya oleh perusahaan dan dapat menambah wawasan bagi mereka yang membacanya.

Adapun saran-saran tersebut antara lain :

$\checkmark \quad$ Untuk meningkatkan efektifitas kompetensi terhadap karyawan, maka peneliti menyarankan kepada pihak PT. Hijau Lestari Raya Fibreboard Pematang Palas untuk meningkatkan pengetahuan dan keterampilan karyawan dengan cara di ikutkan pelatihan-pelatihan yang dibutuhkan oleh karyawan PT. Hijau Lestari Raya Fibreboard Pematang Palas. Dengan demikian karyawan dapat mengembangkan keterampilan dan kemampuan karyawan dalam bekerja.

$\checkmark \quad$ Untuk meningkatkan kinerja karyawan maka peneliti menyarankan kepada PT. Hijau Lestari Raya Fibreboard Pematang Palas untuk memberikan insentif kepada seluruh karyawan agar dapat mening katkan semangat kerja karyawan.

$\checkmark \quad$ Untuk penelitian selanjutnya di sarankan untuk memperluas penelitian dengan cara menambah variabel penelitian agar perusahaan lebih efektif menentukan langkah-langkah dalam meningkatkan kinerja karyawan.

\section{DAFTAR PUSTAKA}

Basori, Miftahul Ainun Naim. dkk. 2017. Pengaruh Kompetensi dan Lingkungan Kerja Terhadap Kinerja Karyawan Melalui Motivasi Kerja Sebagai Variabel Intervening PT. Krakatau Bandar Samudera. Jurnal Riset Bisnis dan Manajemen Tirtayasa, Volume 1 nomor 2,157.

Kadarisman. 2012. Manajemen Pengembangan Sumber Daya Manusia. Jakarta: PT. Raja Grafindo Persada.

Lestari, Dela. 2013. Pengaruh Insentif Terhadap Kinerja Karyawan PT. PLN (Persero) Penyaluran dan Pusat Pengaturan Beban (P3B) Sumatera UPT Palembang. Palembang: Universitas PGRI Palembang.

Mangkunegara, Anwar Prabu. 2013. Manajemen Sumber Daya Manusia Perusahaan. Bandung: PT. Remaja Rosda Karya.

Oktariansyah. 2018. Pengaruh Insentif Terhadap Produktivitas Kerja Karyawan CV. CST Virtual System Singapore Region Sumatera. Jurnal Media Wahana Ekonomika, Vol 15 No. 1 April 2018, Hal: 77-90.

Priyatno, Duwi. 2014. SPSS 22 Pengolahan Data Terpraktis. Yogyakarta: Andi Offset. 
Santoso, Budi Fahrul. 2016. Pengaruh Pemberian Insentif dan Kompetensi Terhadap Kinerja Karyawan PG. Madukismo Yogyakarta. Universitas Negeri Yogyakarta.

Sedarmayanti. 2014. Sumber Daya Manusia dan Produktivitas Kerja. Jakarta: Mandar Maju.

2017. Manajemen Sumber Daya Manusia. Bandung: PT. Refika Aditama.

Sugiyono. 2017. Metode Penelitian Kuantitatif Kualitatif dan $R \& D$. Cetakan ke-25. Bandung: CV Alfabeta.

Sujarweni, Wiratna. 2014. SPSS Untuk Penelitian. Yogyakarta: Pustaka Baru Press.
Suwatno, dan Priansa. 2011. Manajemen SDM Dalam Organisasi Publik dan Bisnis. Bandung: Alfabeta 2013. Manajemen SDM Dalam organisasi Publik dan bisnis. Bandung: Alfabeta

Wibowo. 2014. Manajemen Kinerja Edisi Keempat. Jakarta: PT. RajaGrafindo Persada. 2017. Manajemen Kinerja Edisi Kelima. Cetakan ke-10. Jakarta: Rajawali Pers.

Yani, Muhammad. 2012. Manajemen Sumber Daya Manusia. Jakarta: Mitra Waca Media. 